\title{
China's Balance of Payments Evolution From Deficit to Sustainability Surplus
}

\author{
Doaa Wafik $^{1, *}$ and Assem Tharwat ${ }^{2}$ \\ 1 Higher Institute of Administrative Sciences Egypt. \\ 2 American University in the Emirates, UAE. \\ * Corresponding author: doaawafik@gmail.com
}

\begin{abstract}
China's experience has aroused much controversy in international societies, as it has become a guiding experience for many developing countries seeking economic growth and the treatment of external imbalances (deficits), and this experience has been known for their macroeconomic breakthroughs at all levels. In the beginning the communist regime, the main task of the Chinese was to restore and rehabilitate the country after the war, as well as the legacy of the past economic backwardness and population pressure, establishing the "New China".

During the same period the Chinese suffered from years to the external deficit. The policy of reform and the open door was adopted, until the deficit completely vanished in the mid-1990s and even turned into a surplus of current and financial balance and hence a surplus in the total balance. In this paper, the development of China's balance-of-payments components and transition stages will be analyzed using some statistical tools. The evolution of economic variables affecting external balance, that motivated China to reach the most important corrective measures to remedy the external deficit, as well as the basic pillars on which it depended to sustain the surplus in the balance of payments.

The Egyptian economy is considered one of the most important indicators that reflect the Egyptian economy's external situations and the extent of its disorders resulting from both internal and external causes and drawing the most important lessons from China's experience to benefit from them in confronting and reducing Egypt's external deficit. A comparison will be conducted between the two countries with a discussion for the beneficial lessons that been implemented in the Egyptian context.
\end{abstract}

Keywords: External imbalances, Balance-of-Payments, Economic Growth, Sustainability Surplus, Statistical Analysis

\section{1-Economic analysis for the stages of development of China's balance of payments}

China's balance of payments has gone through four stages according to the economic changes witnessed in the economy. The first stages from 1982 till 1989 and is known as the beginning of the stage of reform and opening-up, as China started to develop foreign trade and simple contribution of foreign capital, this period saw an increase in debt in the form of bonds and loan [22]. The second stages from 1990 till 1993, the economy has shifted to a stage of 
global openness, with foreign trade activities becoming progressively active, with the commodity trade balance having a surplus, especially in the export of industrial products, and thus a current account surplus other than 1993 has achieved a deficit. The third stages from 1994 till 2011, was characterized by the phenomenon of double surplus. In 1994, The authorities implemented the foreign exchange management system, which consolidated the official and market exchange rate by reducing the official yuan exchange rate by $50 \%$ to 8.7 yuan (US dollars), which helped attract foreign direct investment significantly, greatly increasing the surplus of the financial account as it exceeded the account surplus Ongoing. As China joined the World Trade Organization in 2001. This led to a decline in trade barriers, jumps in the current and financial account and accumulation of reserve assets. The current account reached its peak in 2008, reaching 402.6 billion dollars, while the capital and financial account balance reached about 37 billion dollars. [24]. The fourth stages of 2012-present, known as the phase of attracting foreign direct investment and implementing a strategy (belt and road), will witness the current account registration for upward growth but at a rate lower than before 2012. China has been transformed from being an importing country and a recipient of foreign investment to its countries with large-scale foreign investment. The research will address the analysis of China's balance of payments path from 1982, where the process of reform, the revitalization of the domestic economy and the opening to the outside world until 2017.

\section{2- Corrective measures taken by China to remedy the external deficit}

As a first step China determine the causes of the external economic deficit in the 1980s and early 1990s by studying this period and the economic changes in China, the external deficit in this period is only a reflection of imbalances in the domestic economic environment. [27].

The following points summarize the main reasons:

i. The excessive increase in total demand (spending) beyond income is due to the population increase and the concomitant resource weakness, and China was taking the first steps in the development process, which has led to increased production, encouraging individuals to increase consumer and investment demand more than income.

ii. The increase in the supply of cash due to the expansion of credit is due to the increase in government expenditure over revenue (i.e. a financial deficit), so the credit base has been increased. Companies have increased their imports in the absence of adequate expansion of working capital. This large financial deficit was financed by overdrafts of banks and issuance of treasury bills.

iii. Increasing bank loans increased the gap between deposits and loans, which in 1985 and 1988 was about $140 \%$ and $370 \%$ respectively (compared to 1983). The fiscal deficit and the expansion of bank credit have led to a significant increase in the supply of cash, stimulating domestic demand and encouraging increased imports.

iv. Structural imbalance and lack of effective supply, which impedes export, increases in foreign exchange resources and even stimulates the import process. Most exports are 
made up of raw materials needed by the domestic economy and a weak industrial base, because the industrial activity of State-owned enterprises has been ineffective. While private sector contributions to economic activity have been constrained.

v. Distortion of price mechanism This is due to the high value of the local process and the inability to convert it as well as the separation of domestic prices from global prices.

The second step China determine the corrective measures to remedy the external deficit in the 1980s and early 1990s by taken measures and regulations to remedy the balance-ofpayments deficit by eliminating the causes of instability in social and economic development and thus redressing the external deficit and thus helping the national economy to develop in a sustainable and stable way. It has begun to use indirect means through which aggregate demand is controlled by adjusting the spending policy and using direct administrative regulation, whereby the government is strongly adjusting the balance of payments situation by strengthening control or administrative legislation, such as tightening central planning. And administrative laws and regulations relating to foreign currency and foreign trade. Therefore, disability treatment measures have worked on two axes:

\section{A. First axis:}

\section{Reducing the total demand, since the mid-1980s, by implementing the following} actions:

\section{i. Strengthening credit control:}

At the beginning of the reform in 1978, China relied on credit as the largest financial resource for investment financing, so China aimed at increasing domestic liquidity - in a narrow and understandable sense - at the beginning of the reform period, the state was setting up a so-called credit plan that would grant state banks credit quotas used for investment activities and others. This gives banks the power to estimate lending activities, and the credit process at the beginning of the reform period was low-cost. There was therefore an expansion of credit to the degree that the monetary authority could not control at the time, since most credit was directed to stateowned enterprises with limited budgets, which were heavily borrowed for investment financing, and wage bill coverage that had risen by about $45 \%$ in early 1984 , the rate of credit growth rose from $9 \%$ annually to $76 \%$ in late 1984 . In 1985 , aggregate demand increased due to increased investment and consumer demand, which led to increased imports and thus a trade balance deficit and higher inflation. The authorities reacted to external instability and trade imbalance if they pursued restrictive credit policies, by controlling the lending of the central bank to specialized banks and raising interest rates. In 1986, credit schemes were reduced, and banks were free to set interest rates in 1988 and credit quotas were abolished, and a framework for direct contact management was established in cash and credit totals. These amendments were the response to the required expansion of the decision-making authority of the institutions [19].

\section{ii. Raising interest rates on deposits and loans :}

Prior to 1993, interest-rate performance had a weak impact on economic variables, most notably credit and domestic liquidity, due to the slow pace of liberalization of lending and deposit rates but beginning in 1993 the central bank took control of interest-rate control as a political tool Cash, and 1996 interest rates have been liberalized and since then volatility has 
gradually expanded around standard lending and deposit rates. The final step in liberalization was taken in October 2004, and commercial bank lending rates began to move up from $90 \%$ of the reference price, and the minimum deposit rates were canceled.

\section{iii. Some state-owned companies have been closed, suspended, merged and transferred.}

Because of the problems caused by state-owned enterprises, most of the companies have been reorganized, and the economy has gradually shifted from state-owned to foreign-owned enterprises, which have played an important role in China's development [20]

\section{B. Second axis:}

\section{Regulating and strengthening China's external economic relations by implementing the following actions:}

In the light of the government's total loss of control over the management of external economic conditions, the decision-making department of the government has approved the encouragement and encouragement of local and corporate communities to the need and importance of strengthening the functions of central macroeconomic management over foreign trade and foreign exchange. China has done so by: Applying the strategy of developing foreign trade, attracting foreign direct investment, geographical targeting through the opening of special economic zones, and changing foreign exchange regimes.

\section{i. Application of the strategy for developing foreign trade}

The strategy for developing foreign trade has been gradually in place since the beginning of the reform period, beginning in 1980, the export development strategy began through laborintensive sectors such as textiles, clothing and footwear, but export incentives were marginal in terms of import compensation. Thus, starting in 1984, export promotion measures were formally established: Export tax rebates, export subsidies, foreign currency retention quotas, but trade barriers related to imports, quota requirements and licensing remained high.

Beginning in 1986, work began on developing foreign trade through an export support and incentive system. In terms of the targeted sectors, China has targeted export-oriented sectors, including light industrial products, textiles, machinery and electronic goods, with the seventh five-year plan (1986-1990) providing for the establishment of Production Network Exports (PNEs).

One of the most important sectors targeted by China is the electronics sector, in 1985 a decision was made on investment financing from the Ministry of Trade and Industry for the electronics sector, which was about 1300 companies working in machinery and electronics, in addition to increasing the foreign exchange return shares of the companies working in this field. In 1992, it modified the commercial credit system in foreign currency, where buyers for machinery and electronics get $\$ 1$ million per operation [15] .

\section{ii. Opening special economic zones:}

Since the beginning of the 1979 reform period, China has begun geographical targeting by developing special economic zones for testing (special policies and more flexible measures). The experience of the special economic zones has transformed China into one of the largest recipients of foreign direct investment, the largest exporter and the largest foreign exchange reserve in the world. The stages of the emergence and development of China's special economic 
zones are divided into three stages. [15]

\section{iii. Procedures and laws enacted to attract foreign direct investment:}

Foreign Direct Investment (FDDI) in China was used in 1979 as part of the economic reform and opening-up policy that began in December 1978. To accelerate the country's economic modernization, the new policy promoted China's participation in and access to international trade. Foreign direct investment (FDI) is the best way to introduce foreign capital, absorb modern technology and managerial skills, and as we have already stated, it has combined export promotion with strong import protection measures. Protection of imports from major export barriers is usually because they raise the cost of capital goods and intermediate inputs required to produce goods, which makes domestic prices higher than they are. Thus, the domestic market is more attractive than the world, so it has resorted to incentives to attract foreign investment but gradually [9].

\section{iv. Repairs to the system of drainage:}

The exchange system used from 1981 to 1984 was the dual exchange rate system, and the general trend was to reduce the value of the local currency: The official rate had gradually decreased, while the secondary rate, which had been used to reduce the value of the local currency. Internal Settlement Rate applicable to commercial transactions, fixed at a lower rate of RMB 2.8 per US dollar, whereas the official exchange rate was RMB 1.5 per US dollar (secondary rate reached by adding $10 \%$ of the average export cost in 1979). These changes were essentially a mechanism for promoting exports and improving the position of the trade balance, as exporters could have gained more local currency against the US dollar through the sale of goods in foreign markets. It was also a means of dealing with financial loss problems due to increased subsidies for the export sector. End ISR canceled

Starting in 1985, several measures were taken to promote foreign trade, first unifying the exchange rate at 2.8 yuan against the dollar after the official price drop, and the government adopted the (managed floating) system, and the foreign exchange department amended the exchange rate down by a three-fold margin. The exchange rate against the dollar fell from 2.80 yuan to 4.73 yuan, a 69 percent decrease in the treatment of the external deficit, and other falls to 5.43 yuan against the dollar in 1991. Second, amendments were made to the system of foreign exchange retention quotas to provide incentives to exporters, especially in the special economic zones, in May 1985. Thus, the two-track exchange system was reintroduced the same year and foreign and domestic enterprises in the economic zones of foreign exchange held between them can exchange rates negotiated in the centers [6].

\section{3- Phases of Egyptian balance of payments development}

\section{A. Phase I: The Egyptian balance of payments developed in the period from (1977-1990).}

The stage of economic openness. Egypt started to apply the policy of economic openness since 1974 to increase the productive efficiency and increase the growth rates by opening the door for Arab and foreign investment and calling on the private sector to contribute to the development process. One of the first steps taken in this regard is the promulgation of Act No. 43 of 1974 on the Investment of Arab and Foreign Capital and Free Zones, which includes tax and customs exemptions for a few years according to the type of project. Securing the investor's right to transfer his profits, recover his capital and secure it against non- 
commercial risks such as confiscation and nationalization. In addition to Act No. 118 of 1975, It states that the process of importing commodity needs according to the general plan of the state through the public and private sectors shall be carried out within the limits of the monetary budget approved on the condition that the right of import should be universal except for some commodities that affect the citizen's interest such as strategic commodities such as wheat, in addition to restricting imports from some countries to Public sector. Regarding the trade policies, a tariff structure was issued in 1980 according to the degree of industrialization, where the nominal tariff for raw materials ranged from $15 \%$ to $40 \%$, while consumer goods are subject to nominal tariff ranging from $150 \%$ to $175 \%$. [4].

In the monetary sector, several measures have been taken to develop the parallel market for foreign exchange, which opened the door for determining the exchange rate based on supply and demand forces, in addition to allowing the importation of self-resources, which is called (importation without currency conversion). Another regulation issued to handle of foreign currency had also been enacted, which had ensured citizens the freedom to keep foreign currency without asking the source. This policy has achieved a rise in real growth rates to an average of $9.6 \%$ per annum during the period from 1974 to 1979 but has fallen to an average of $7.4 \%$ until the first half of the 1980s [3].

\section{B. Phase II: Evolution of the Egyptian balance of payments in the period 1991-2000. "Economic reform and structural adjustment program".}

As of Egypt's structural imbalances in the national economy, which led to imbalances in the internal and external balance of the Egyptian economy. Egypt resorted to the International Monetary Fund to borrow to solve the economic problems that aggravated in the second half of the 1980s, which was under the framework of the economic reform and structural adjustment program. The program involves a package of policies that include many fiscal, monetary and structural reforms whose main objective is to coordinate external balance with domestic economic balance and reconcile them as far as possible using fiscal and monetary policy with structural policies and include (industrial, investment and trade) or what economists are called best economic policy-makers. These reforms are summarized in the following points $[1,2]$.

i. Reducing import tariffs and removing non-tariff barriers to create a favorable climate for attracting investment.

ii. A sales tax to increase government revenues.

iii. Reducing support to groups in need.

iv. To allow the private sector and to reduce the role of the public sector through privatization.

v. Rationalizing government spending through raising the prices of fuel, electricity and communications (reducing subsidies) and freezing the wages of the public sector.

vi. Encouraging private sector investment in all sectors.

vii. Edit the interest rate.

viii. Using new financial instruments to fill the budget deficit, such as treasury bills.

Egypt has undertaken several reforms to achieve the external economic balance (balance of payments), working on two axes: Policies relating to foreign trade and exchange-rate policies. About exchange-rate policies, on 27 February 1991 Egypt took the first steps to reform 
the foreign exchange market, which is to abolish the multiplicity of exchange rates, unify the exchange rate and tie the dollar, and the foreign exchange system consists of a primary market and a free market. The exchange rate in the primary market is determined daily by about $5 \%$ less than the average exchange rate prevailing in the free market in the last seven working days. This means that the exchange rate prevailing in the free market is regulated by the exchange system. In addition to allowing companies exchange by dealing with foreign exchange in the free market and cancelling the budget of public sector companies from foreign exchange. [7].

As for foreign trade policies, the Government has taken steps to transform the Egyptian economy into an open, low-duty economy, as follows: About imports, the list of goods whose import is prohibited has been gradually reduced from 1991 until they were completely abolished in 1993/94. In addition to narrowing the gap between the maximum and the minimum tariff, by raising the minimum to $10 \%$ and lowering the maximum to $50 \%$ at the end of 1992 . It has been modified more than once until 1996 to reach a minimum of $10 \%$ and a maximum of $25 \%$ by a republican decision. In addition to taking measures to stimulate domestic and foreign investment, the government reduced the tariff on capital goods to 5\% and $10 \%$ and eliminated the tax on capital profits on shares and bonds in mid-1996, which was $2 \%$. About exports, the number of goods prohibited from exporting from 20 to two, namely minerals as scrap or raw materials, the elimination of export quotas for many commodities in 1992, the cancellation of pre-export approvals and the elimination of qualitative control over many export commodities.

In 1991, the Government issued treasury bills for the first time to absorb liquidity and reduce overall demand, and in 1995, treasury bonds were issued for a period of five to ten years. These reforms have had an impact on both the balance of current transactions and the financial and capital budgets. [12].

\section{Phase III: Development of Egyptian balance of payments in the period 2001-2010.}

This period witnessed many reform measures that aimed at developing export capacity, as Egypt has developed an integrated strategy for developing exports in 2001, as this strategy aimed at increasing Egyptian exports from 2001 to 2003. The strategy included three main axes: Strengthening the institutional infrastructure for export, strengthening the international movement for export development and sectorial policies. [11].

Among other things, Egypt's signing of the European Partnership Agreement in 2001 and its adherence to the internationally agreed rules and bases, especially in the field of export subsidies, which entered into force in 2004, allowed the free entry of Egyptian products into the European market, while European products will await Twelve years until its gradual entry into the Egyptian market is liberalized, and in 2004, a comprehensive reform of the Egyptian Customs Administration was initiated, and modern customs centers were established at the main ports and new information technology systems were launched to facilitate communication between ports and airports, and these systems became operational in 2009.

With regard to trade liberalization on commodities, several measures have been taken that have reduced the nominal protection rate and the effective protection rate, especially in the manufacturing sector, the tariff ceiling has been reduced from 50\% in 1997 to $43 \%$ at the beginning of the millennium (After excluding tariffs on some goods such as alcohol and cars 
that exceed the above limits by a large margin. As for the unlikely milieu of customs tariff on imports, it fell from $25.9 \%$ in 1994 to $20.4 \%$ in 2002, while the likely medium fell from $16.2 \%$ in 1994 to $13.5 \%$ in 2002, while products from manufacturing sector fell in the unlikely middle from $26 \%$ in 1994 to $20.7 \%$ in 2002 . The likely medium decreased from $19.6 \%$ in 1994 to $15.9 \%$ in 2002 . In 2004, the likely average tariff on all goods fell to $8.9 \%$, and the higher tariff limit fell to $40 \%$, as it was applied to television sets and cars with a capacity not exceeding $1600 \mathrm{~cm} 3$, with the higher limit of larger cars, alcoholic drinks and smoke remaining above $40 \%$. At the beginning of 2005, some amendments made the tariff level lower than the level of linking Egypt to the World Trade Organization (WTO). In 2009, the Ministry of Trade and Industry announced the Export Development Strategy for the period 2010 to 2013, focusing on coordination between government agencies, stakeholders and the private sector to achieve the desired goal of developing trade policy to deepen integration into the world economy [10].

Regarding the editing of services, Egypt has taken more rapid steps in the field of liberalization of services than it has committed within the framework of the World Trade Organization. Egypt signed the fourth protocol on services agreements (GATS) in 2002, pledging to end the monopoly of the public sector in telecommunications services by 2005 , which led to the privatization of part of the public sector company in this field and the opening of the door for the private sector to privatize insurance companies after the completion of sterilization and restructuring operations. Services have been liberalized in many sectors identified by the World Trade Organization (WTO) and include construction, construction, transport, financial services and tourism. Egypt offered to expand the scope of liberalization in these sectors to include other sectors, namely information technology, computer services [5].

\section{Phase IV: Evolution of Egyptian Balance of Payments (2011-2017).}

This evolution period has witnessed many political developments, both domestic and regional, which necessarily have affected internal and external economic conditions. This period saw two points of transition, the first in 2011 since the eruption of the revolution, the political turmoil that had had a great impact on the internal and external economic imbalance, and the second from November 2016, the beginning of the second economic reform program. The first period since the eruption of the revolution on 25 January 2011, political instability has significantly affected the Egyptian economy and led to a severe slowdown in growth rates, which began after the 2011 revolution, with GDP falling far below its potential. Investment and exports declined, while consumption was supported by remittances from abroad and ongoing government spending. The total fiscal deficit widened from 7 to $8 \%$ of GDP before the revolution to $10-13 \%$ after the revolution. Public debt increased from $70 \%$ of GDP in $2009 / 2010$ to $89 \%$ in $2014 / 2015$ and interest payments amounted to about one third of total budget expenditures (about 9\% of GDP). The deficit was financed through bank borrowing, about one third of the central bank's direct funding. The monetary policy kept inflation high as the exchange rate stabilized, which led to overestimation of the pound value. In June 2016, total international reserves amounted to $\$ 17.1$ billion, equivalent to 3.1 months of expected imports, $76 \%$ of the fund's floating system reserve (ARA) reserve scale and $45 \%$ for fixed systems. Although Saudi Arabia's agreement to provide oil import financing for about $\$ 4$ billion a year for five years has eased external pressures, but not enough to address the country's needs full foreign currency. In the face of mounting macro-imbalances, the State has taken 
some measures [13].

First, in 2013, under the European Partnership Agreement, which allows tariff reduction on intermediate goods if the final product has a local component starting from $30 \%$, the higher the tariff rate, the lower the tariff rate, and if the domestic component reaches $60 \%$ and more, the tariff decreases to 90\%. Second, in 2014/2015, the Egyptian Central Bank devalued the Egyptian pound by $5 \%$ and raised interest rates to contain inflationary pressures, but this did not result in tangible gains. For the current account, this period has seen an increasing current account deficit of $\$ 20494$ million. Finally, in 2016. For the balance of trade, the deficit continued to increase to a peak of 2015 , reaching $\$ 31.389$ million from $\$ 19.398$ million in 2010, up 61\%. By analyzing the structure of exports, export earnings fluctuated but declined significantly in 2015 due to fluctuations in world oil prices, which led to a decline in the output of crude exports (which constitute $28 \%$ of commodity exports) despite the increase in crude exports. For the service balance, the decline in service export earnings from 2010/2011 was due to the decline in tourism revenues from $\$ 11.6$ billion in 2009/2010 to $\$ 10.6$ billion and $\$ 9.7$ billion in 2010/2011 and 2012/2013 respectively. In addition, other service receipts fell from $\$ 3.7$ billion in 2009/2010 to $\$ 2.7$ billion and $\$ 2.6$ billion in 2010/2011 and 2012/2013 respectively. As for investment income, its earnings fell by a $49.5 \%$ decline in bond and securities interest in 2010/2011 (compared to the previous year) as well as higher payments from FDI income. The secondary income balance was higher in 2010/2011 due to the high percentage of private transfers, and it is noted that remittances accounted for about $99 \%$ of total private transfers, but official transfers declined by about $21.1 \%$ from the previous year [6].

\section{4-Data Analysis}

To analyze the Revenue, Expenses and Deficits for both China and Egypt, secondary data was used, and some statistical analysis was implemented to support the authors recommendations for the Egyptian Economics. Tables $(1,2)$ see Appendix, represents the historical values of Revenue, Expenses, and deficits in China and Egypt, it is round about values from 1978 to 2017 :

\section{A. China Data analysis:}



Fig. 1: The Chines' Revenue and Expenses. Source: The form was prepared from the IMF database http://data.imf.org/regular.aspx

In Fig 1, It is noticed that China expenses (the red curve) exceeded the revenue after the year 2008 
and the gab increased slightly during the last decay

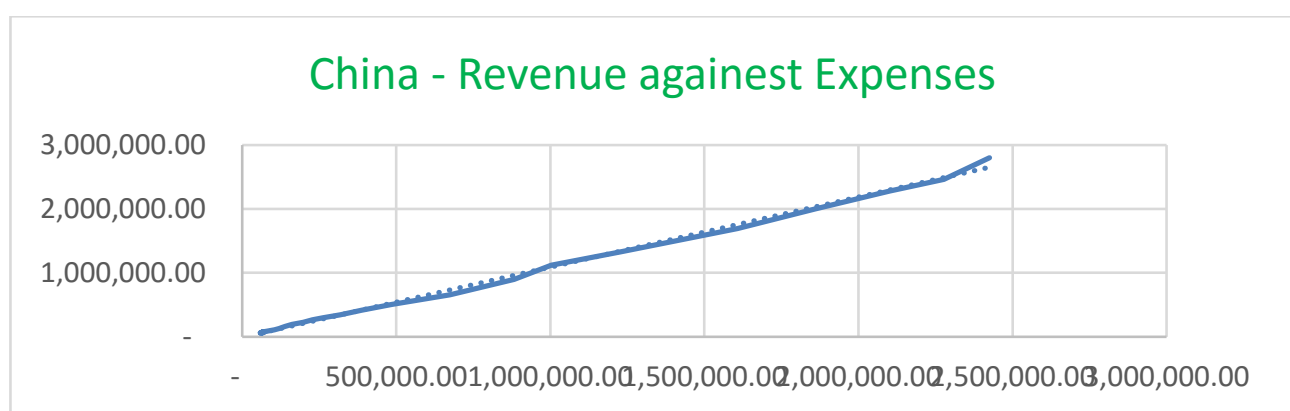

Fig. 2: The relationship between Chines' Revenue and Expenses. Source: The form was prepared from the IMF database http://data.imf.org/regular.aspx

In Fig 2, It is noticed that there is a positive trend between the revenue in China and the expenses and the expected regression line is $\mathrm{Y}=1.0963 \mathrm{X}-5887.1$ with perfect positive correlation and determination coefficient greater than $99 \%$. The relationship is statistically significant with confidence level 0.05 . The extracted relation can predict China expenses $\mathrm{Y}$ for a given revenue $X$.

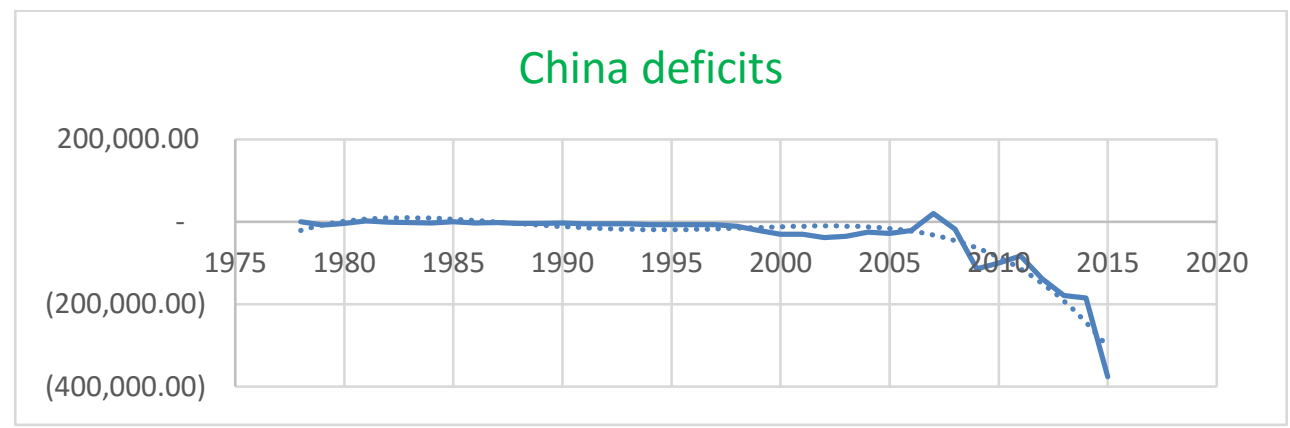

Fig. 3: The Chines' Deficits. Source: The form was prepared from the IMF database http://data.imf.org/regular.aspx

In Fig 3, It is noticed that China deficits has a negative exponential trend and the expected fitting curve is $\quad Y=-1.9505 \mathrm{X}^{4}+15551 \mathrm{X}^{3}-5 \mathrm{E}+07 \mathrm{X}^{2}+6 \mathrm{E}+10 \mathrm{X}-3 \mathrm{E}+13$ with a strong fitting and determination coefficient greater than $90 \%$. The curve is statistically significant with confidence level 0.05 . The extracted relation can predict the Chinese deficits $\mathrm{Y}$ for a given year $\mathrm{X}$.

\section{B. Egypt Data analysis:}

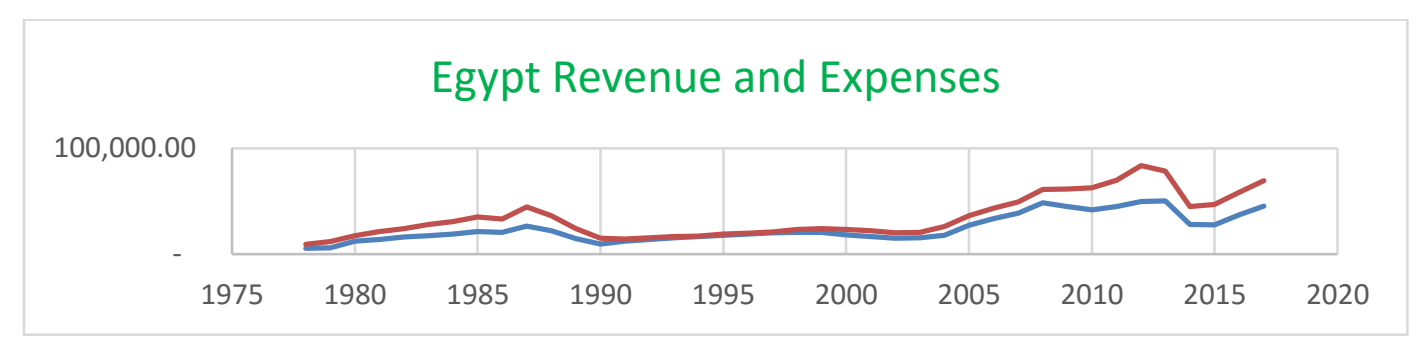

Fig. 4: The Egyptian's Revenue and Expenses. Source: The form was prepared from the IMF database http://data.imf.org/regular.aspx 
In Fig 4, It is noticed that Egypt expenses (the red curve) exceeded the revenue starting from the beginning of the analysis period except during the period of 1990-2000 (the economical remedy period) and the gab increased significantly during the last two decays

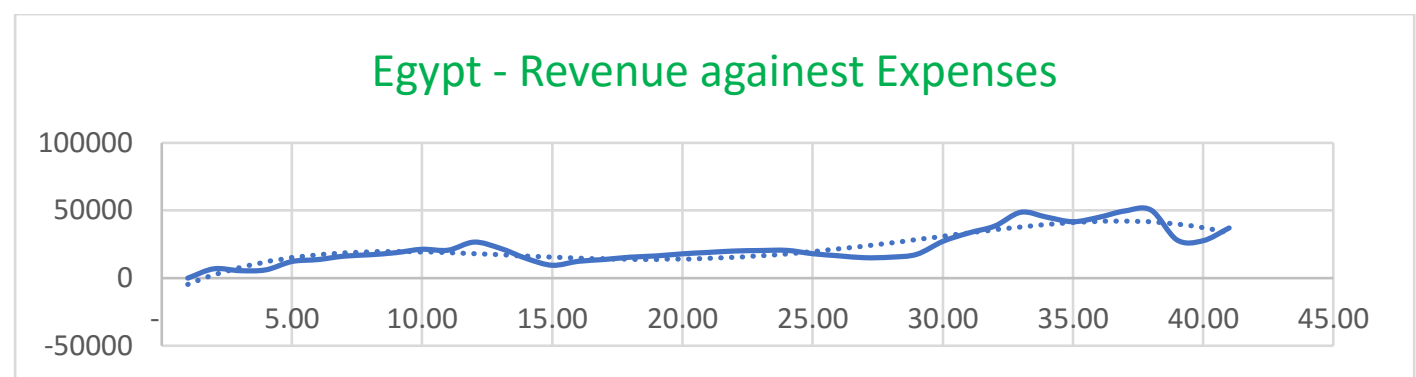

Fig. 5: The relationship between Egyptian's Revenue and Expenses. Source: The form was prepared from the IMF database http://data.imf.org/regular.aspx

In Fig 5, It is noticed that there is a positive trend between the Egyptian revenue and the expenses and the expected regression line is $Y=-0.3856 X^{4}+33.12 X^{3}-912.27 X^{2}+9458.2$ $\mathrm{X}-13222$ with strong fitting and determination coefficient greater than $80 \%$. The curve is statistically significant with confidence level 0.05 . The extracted relation can predict the Egyptian expenses $\mathrm{Y}$ for a given revenue $\mathrm{X}$.

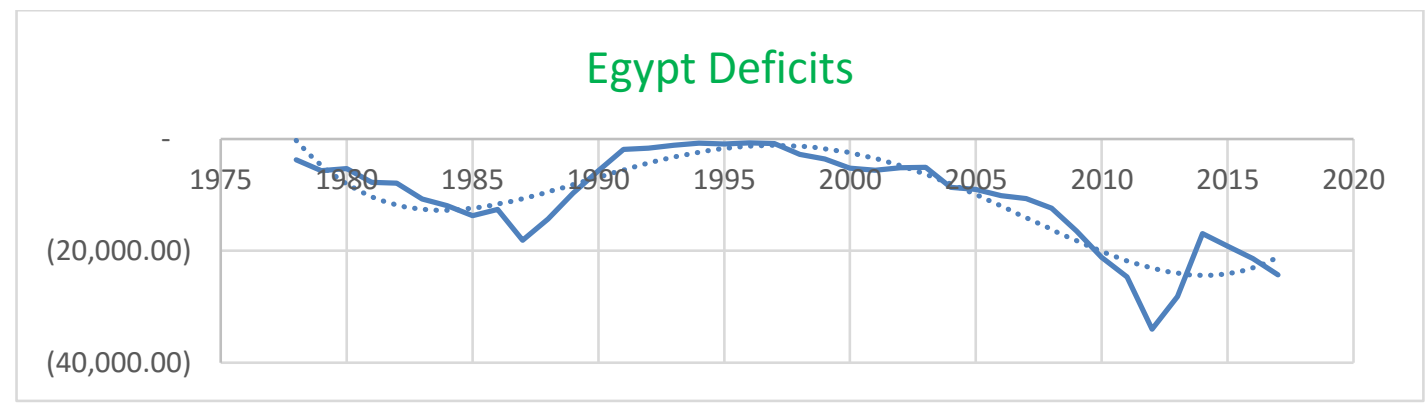

Fig. 6: The Egyptian's Deficits. Source: The form was prepared from the IMF database http://data.imf.org/regular.aspx

In Fig 6, It is noticed that Egypt deficits has a negative exponential trend and the expected fitting curve is $\mathrm{Y}=-0.3856 \mathrm{X}^{4}+33.12 \mathrm{X}^{3}-912.27 \mathrm{X}^{2}+9,458.2 \mathrm{X}-13,222$ with a strong fitting and determination coefficient greater than $80 \%$. The curve is statistically significant with confidence level 0.05 . The extracted relation can predict the Egyptian deficits $\mathrm{Y}$ for a given year X.

The previous figures (Fig 1 - Fig 6) illustrate the overall balance position, which has suffered a deficit in some years because the fiscal and capital balance is unable to cover the current account deficit completely, and we have already mentioned the reasons for the deficit through the analysis of the main balance of payments components. If the financial account is unable to cover the deficit, international foreign exchange reserves are used to cover the deficit. Developments in the overall balance (both surplus and deficit) are calculated based on the change in the reserve assets of the Central Bank, which include monetary gold, SDR units, IMF reserve status and all foreign exchange controlled by the Central Bank and monetary authorities (Includes cash and securities). 


\section{Financial balance (general budget of the State):}

The budget deficit was defined as the difference between gross revenue and total expenditure, but as of 2005 there were several concepts of deficit, namely, cash deficit, initial deficit and total deficit. The cash deficit is the difference between expenditure and income and reflects the amount of income over expenditure coverage. The total deficit is the cash deficit plus net possession of financial assets, and it is the most obvious illustration of the value of the deficit, as the result of which borrowing is made either from internal or external sources.

The budget deficit in Egypt was defined as structural deficit, not that associated with economic cycles, boom and recession, and by estimating the deficit as a percentage of GDP, which was found to be excessive deficit (It exceeds 3\% of GDP), which is the percentage approved by the European Union. In an analysis of the development of the budget deficit in the Egyptian economy, it became clear that the period from 1977 to 1990 witnessed a rise in the budget deficit due to the economic openness policy followed by the country and the tax and customs exemptions offered to investors, which reflected on the decline of public revenues and tax revenues and had a great effect on the rise of inflation rates.

\section{China versus Egypt Analysis}

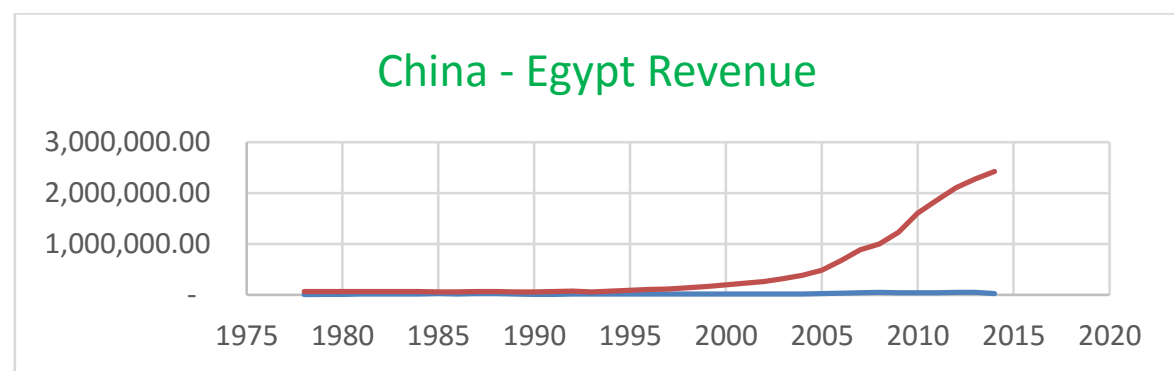

Fig. 8: The Chines versus the Egyptian Revenues. Source: The form was prepared from the IMF database http://data.imf.org/regular.aspx

In Fig 8, It is observed that the Chines revenue (the red curve) start to exceed the Egyptian revenue from 1995 and with a significant increment gab till 2015.

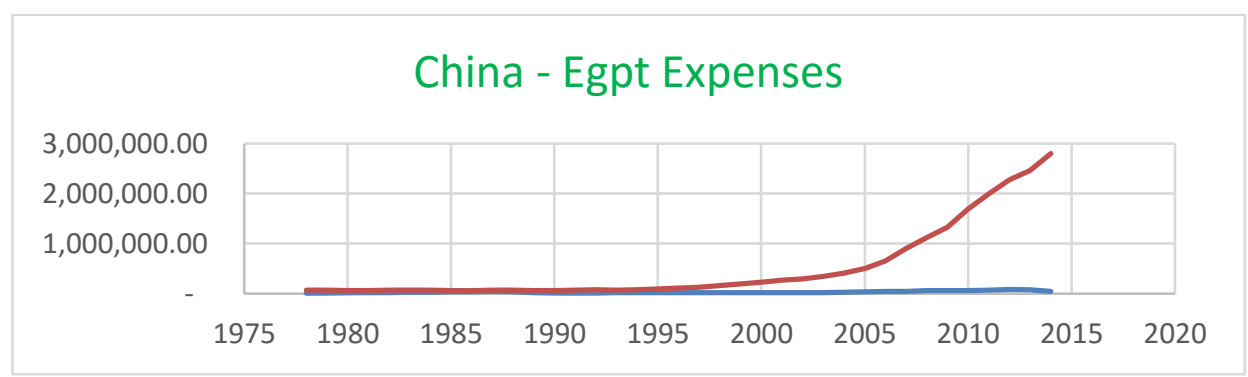

Fig. 9: The Chines versus the Egyptian Expenses. Source: The form was prepared from the IMF database http://data.imf.org/regular.aspx

In Fig 9, It is observed that "contradicts the Revenue curve" the Egyptian expenses (the red curve) exceeds the Chinese expenses with a huge increment gab started 1995. 


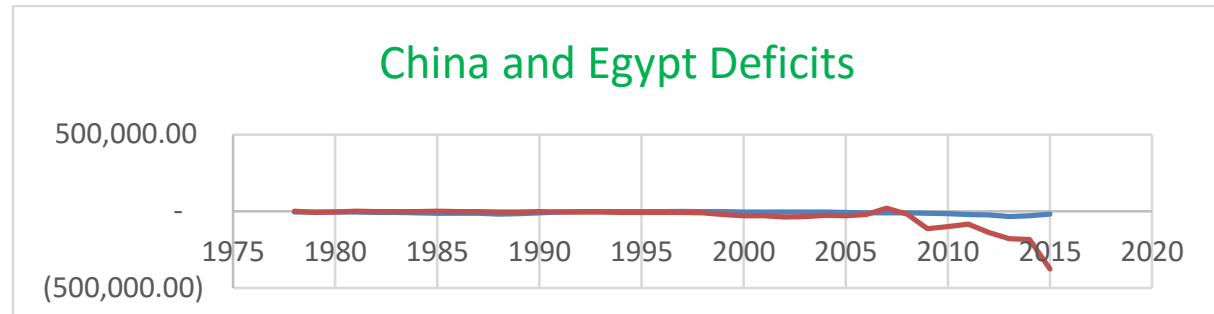

Fig. 10: The Chines versus the Egyptian Deficits. Source: The form was prepared from the IMF database http://data.imf.org/regular.aspx

In Fig 10, It is noticed that Chinese and the Egyptian deficits have almost the same behavior till 2005 and a significant increment had happened during the last decay from the Chines side (the red curve).

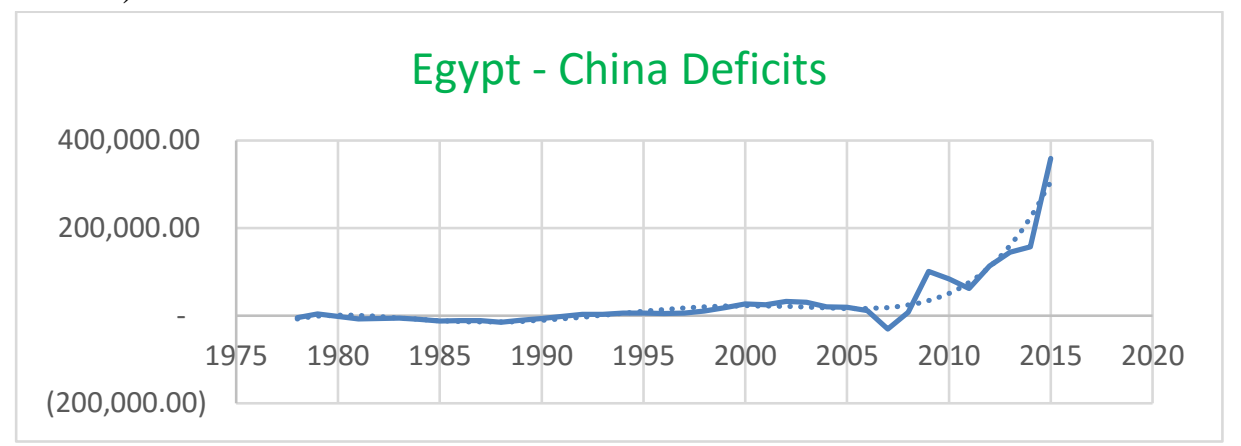

Fig. 11: The relationship between the Chines and the Egyptian Deficits. Source: The form was prepared from the IMF database http://data.imf.org/regular.aspx

In Fig 11, It is noticed that the differences between Chinese and the Egyptian deficits has a positive exponential trend and the expected fitting curve is $Y=0.1393 x^{5}-1388 x^{4}+6 E+06$ $x^{3}-1 E+10 x^{2}+1 E+13 x-4 E+15$ with strong fitting and determination coefficient greater than $90 \%$. The curve is statistically significant with confidence level 0.05 . The extracted relation can predict the differences between the deficits between the two countries $\mathrm{Y}$ for a given year $\mathrm{X}$.

\section{5- Recommendations}

China's experience is unique in how to achieve this amount of surplus in the balance of payments, an experience with many lessons learned in trying to remedy the structural imbalances in Egypt's balance of payments. China has adopted an internal and external reform plan, one of its most important pillars is the mobilization of domestic savings to finance development projects by focusing on industries directed at combating and attracting direct foreign investment directed at stimulating exports, especially the manufacturing sector and the neoliberal sector of modern technology. The following China's experience actions that could contribute to the reform of the external imbalances of the Egyptian economy:

- Raising the real interest rate by lowering inflation rates, not by raising the nominal interest rate.

- Raise savings rates to bridge the financing gap of investments through the dissemination of banking culture and the application of a clear strategy of financial inclusion. 
- Rationalizing domestic credit for the private business sector, regulating it and targeting productive activities, especially value-added manufacturing industries of the local economy.

- Reduction of domestic credit for the domestic sector to rationalize consumer spending and reduce imports. Reduce the expansion of the money supply to reduce spending.

- Preferential incentives for exported goods according to their domestic component ratio.

- Restrictions on imports or investments that are harmful to the domestic product and its accumulation, and restrictions on companies wholly owned by foreigners.

- Activate the strategy for manufacturing and foreign trade developed in 2016, try to implement its target at specific time times and need effective participation from the state and the private sector.

- Linking credit grants to the private business sector to private investment areas aimed at increasing exports of non-petroleum goods and providing them with more easy restrictions.

- Rationalization and limitation of tax exemptions to sectors of value added or export-oriented value added

- Targeting and giving more preferential benefits to FDI that transfers technology or supports exports and amending laws and legislation.

- Direct domestic and foreign investment in accordance with an investment plan established by the State focusing on the productive sectors and manufacturing industries.

- Establishment of export production network (PNEs) in some targeted sectors and improving the investment climate through.

\section{6- Conclusions}

New China considered one of the most economical stable country and it has become a guiding experience for many developing countries seeking economic growth and the treatment of external imbalances (deficits). China's experience is unique in how to achieve this amount of surplus in the balance of payments. Many lessons learned and extracted in trying to remedy the structural imbalances in Egypt's balance of payments. China has adopted an internal and external reform plan, one of its most important pillars is the mobilization of domestic savings to finance development projects by focusing on industries directed at combating and attracting direct foreign investment directed at stimulating exports, especially the manufacturing sector and the neoliberal sector of modern technology. In addition, many recommendations have been summarized to guide the Egyptian improvements for the Economy, including the raising the real interest rate by lowering inflation rates, not by raising the nominal interest rate; raising the savings rates to bridge the financing gap of investments through the dissemination of banking culture and the application of a clear strategy of financial inclusion.

\section{References}

[1] A. P. Thirlwall, "Balance-of-Payments Theory and the United Kingdom Experience", Macmillan press, 2nd Ed. (1986)

[2] A. Eckstein, "China's Economic Revolution”, Cambridge University Press. (1977)

[3] A. P. Cusolito - M. NedeljKovic , "Toolkit for the Analysis of Current Account Imbalances", World Bank. (2013) 
[4] A. Herzberg, "Sustainability of External Imbalances (Critical Appraisal)", Springer Gabler. (2015)

[5] A. O. Akpansung, "A Review of Empirical Literature on Balance of Payments as a Monetary Phenomenon", Journal of Emerging Trends in Economics and Management Sciences (JETEMS). (2013)

[6] A. Panagariya, "China's Export Strategy: What Can We Learn From It?”, International Trade, 0309014, University Library of Munich, Germany. (2003)

[7] A. R. Asrafuzzaman , S. D. Gupta, "An Empirical Investigation of Budget and Trade Deficits: The Case of Bangladesh", International Journal of Economics and Financial Issues, Vol. 3, No.3 www.econjournals.com, 2013

[8] A. Soydan, “Does Credit Growth 'Cause' Current Account Deficits? Evidence from Turkey”, Advances in Economics and Business.2018

[9] Bank for International Settlements, China's Capital Account Liberalisation: international Perspectives, Monetary and Economic Department, BIS Papers, No 15.2013

[10] B. Naughton, "China's Emergence and Prospects as a Trading” Nation. (1996)

[11] BOP Analysis Group State Administration of Foreign Exchange, China's Balance of Payments Report. (2014)

[12] B. Snowdon , H. R. Vane, "Modern Macroeconomics (Its Origins, Development and Current State) “ Edward Elgar, USA. (2015)

[13] Chris Brooks, Introductory Econometrics for Finance. Cambridge University, 2nd Ed. 2008

[14] C. A. Sims, "Macroeconomics and Reality". Econometrica, Vol. 48, No. 1. 1980

[15] C. J. Neely, "Chinese Foreign Exchange Reserves, Policy Choices and the U.S. Economy", Federal Reserve Bank, WP 2017-001A. 2017

[16] D. A. Dickey, W. A. Fuller, "Distribution of the Estimators for Autoregressive Time Series with a Unit Root”. Journal for the American Statistical Association, Vol. 47, Issue 366. 1979

[17] D. A. Dickey, W. A. Fuller, "Likelihood Ratio Statistics for Autoregressive Time Series with a Unit Root". Econometrica, Vol. 49, No. 4, 1981

[18] P. D. Kwiatkowski, C. B. Phillips, P. Schmidt, Y. Shin, "Testing the Null Hypothesis of Stationary against the Alternative of a Unit Root". Journal of Econometrics, Vol. 54, Issues 1-3, 1992

[19] D. Salvatore, "International Economics" John Wiley, 7th Ed. 2017

[20] D.S. Kemp, "Balance-of-Payments Concepts — What Do They Really Mean? “ Federal Reserve Bank of ST.Louis. 1975. 